\title{
Prevalence of subclinical thyroid disorders in type 2 diabetes mellitus
}

Satvic C. Manjunath, Vishwanath Krishnamurthy, Balaraj K. Puttaswamy, Srinivasa Prabhu, Poornachandra M. Vishwanathaiah

Department of General Medicine, Kempegowda Institute of Medical Sciences, Bengaluru, Karnataka,

India

Address for the Correspondence:

Dr. Satvic C. Manjunath, Department of General Medicine, Kempegowda Institute of Medical Sciences, Bengaluru, Karnataka, India. E-mail: satviccmanjunath@gmail.

com

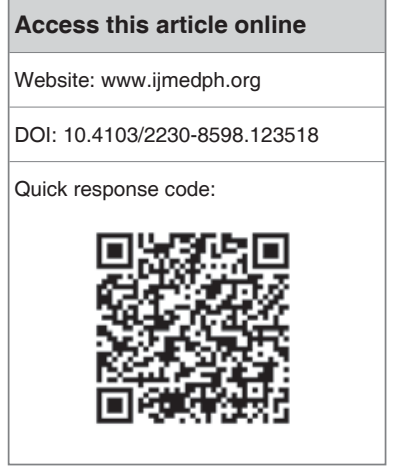

Background: Subclinical thyroid disorders usually do not produce symptoms of thyroid disease until they turn into over thyroid disease. Thyroid disease is more common in people with diabetes mellitus than in the general population and it is important to detect thyroid disorder before its clinical manifestation. Subclinical hypothyroidism (SCH) can produce dyslipidemia, obesity thus resulting increased predisposition to coronary artery disease. Subclinical hyperthyroidism can aggravate hyperglycemia and impair blood sugar control. Objectives: Our objective is to determine the prevalence of subclinical thyroid disorders in patients with type 2 diabetes mellitus (T2DM) and to analyze the clinical and metabolic profile of patients with this dual endocrine disorder. Methods and Results: One hundred consecutive type 2 diabetic patients without clinical manifestations of thyroid disorders were screened for $\mathrm{SCH}$ and subclinical hyperthyroidism using serum free $\mathrm{T}_{3^{\prime}}$ free $\mathrm{T}_{4}$ and thyroid stimulating hormone (TSH) levels. Individuals of subclinical thyroid disease were further screened for thyroperoxidase (TPO) antibodies. SCH was detected in $13 \%$ of type 2 diabetic patients and none had subclinical hyperthyroidism in our study. SCH was common among females with type 2 diabetes (84.6\%). Elevated TPO antibody levels were present in $84.6 \% \mathrm{SCH}$ patients. Diabetic retinopathy among $\mathrm{SCH}$ patients showed significant association with higher serum TSH levels. Left ventricular diastolic dysfunction was present in $30.8 \%$ of $\mathrm{SCH}$ patients. Conclusion: $\mathrm{SCH}$ is common among type 2 diabetic patients, especially in females. It is most commonly secondary to autoimmune thyroid disease. Microvascular complications are commonly observed in this group of patients with dual endocrinal disorder and treating physician should be aware of the impact and should routinely screen $\mathrm{SCH}$ to prevent complications.

Key words: Anti-thyroperoxidase antibody, diabetic retinopathy, left ventricular diastolic dysfunction, subclinical hypothyroidism, subclinical hyperthyroidism, type 2 diabetes mellitus

\section{INTRODUCTION}

The prevalence of thyroid disease in the diabetic patients is significantly higher than in the general population. ${ }^{[1]}$ Apart from autoimmune etiology linked to the higher prevalence of thyroid disease in diabetes mellitus; it has also been observed that thyroid function is intrinsically linked to insulin resistance. It has also been stated that common factors simultaneously are responsible for increased thyroid stimulating hormone (TSH) levels and insulin resistance. ${ }^{[2]}$

In type 2 diabetes mellitus (T2DM), prevalence of thyroid disease has been found to be as high as $31 \%$, the most common disorder being subclinical hypothyroidism, followed by subclinical hyperthyroidism, overt hypothyroidism and overt hyperthyroidism. ${ }^{[3]}$ Subclinical hypothyroidism $(\mathrm{SCH})$ is defined as a serum TSH level above normal despite normal levels of serum free thyroxine. ${ }^{[4,5]}$

$\mathrm{SCH}$, in various studies, has been shown to be associated with elevation in serum lipids, coronary artery disease and left ventricular (LV) diastolic dysfunction, LV systolic dysfunction with exercise, increased peripheral vascular resistance and mental depression.

\section{Objectives}

1. To determine the percentage of subclinical thyroid disorders in patients with T2DM.

2. To study the clinical and metabolic profile of patients with this dual endocrine disorder. 


\section{MATERIALS AND METHODS}

This study was done at department of general medicine, Kempegowda Institute of Medical Sciences, Bangalore. This is a cross-sectional observational descriptive study. A total of consecutive 100 type 2 diabetic patients (50 male and 50 female patients) aged $>40$ years, with no past history of thyroid disorder were included in the study. Patients younger than 40 years of age on drugs known to alter thyroid hormonal levels, seriously ill-patients, patients previously diagnosed with thyroid disorder and on medication, patients with the chronic conditions known to alter thyroid function, such as hepatic dysfunction, pregnancy and psychiatric illness were excluded from the study. Written informed consent was taken from all patients and the study was approved by institutional ethical committee. All the study participants underwent detailed history, clinical examination and laboratory investigations using pro forma designed for this study. Special emphasis was given to symptoms and signs of hypothyroidism and hyperthyroidism.

All patients were subjected to following investigations: Fasting blood sugar (FBS), post-prandial blood sugar (PPBS), hemoglobin A1c (HbA1c), Serum free $\mathrm{T}_{3}$, free $\mathrm{T}_{4}$, TSH, Fasting lipid profile, ECG, 2D Echocardiography, Ophthalmological evaluation (fundus examination), Urine routine, Blood urea, serum creatinine. Serum anti-thyroperoxidase (TPO) antibody assay was done in patients detected to have subclinical thyroid disease.

$\mathrm{SCH}$ was defined as serum TSH $>4.2 \mu \mathrm{IU} / \mathrm{ml}$, with normal levels of serum free $\mathrm{T}_{4}(0.93-1.7 \mathrm{ng} / \mathrm{dl})$. Anti-TPO antibodies were measured by immunoenzymatic assay using $0.5 \mathrm{ml}$ of patient's serum sample and values $>9.0 \mathrm{IU} / \mathrm{ml}$ were interpreted as elevated.

\section{Statistical analysis}

Descriptive statistics were presented as mean \pm standard deviation for continuous measures while absolute values and percentages for categorical measures. All analyses were conducted using the Statistical Package for the Social Sciences (SPSS) 16 statistical software (SPSS Inc., Chicago, Illinois, USA). A $P<0.05$ was considered to be statistically significant throughout the analysis. The difference between different parameters based on quantitative variables are compared using Student's $t$-test for independent samples and the difference is considered statistically significant when the $P<0.05$.

\section{RESULTS}

In the present study, a total number of 100 patients of T2DM underwent thyroid function test including serum free $T_{3}$, free $\mathrm{T}_{4}$ and TSH. Based on the above biochemical values, it was determined that out of the 100 patients [Table 1], 84 were euthyroid (serum TSH, serum free $\mathrm{T}_{4}$, serum free $\mathrm{T}_{3}$ within normal limits), 13 patients had SCH (serum TSH $>4.2 \mu \mathrm{IU} / \mathrm{ml}$ with normal levels of serum free $\mathrm{T}_{4}$ ) and the remaining $3 \mathrm{had}$ overt primary hypothyroidism (serum TSH $>4.2 \mu \mathrm{IU} / \mathrm{ml}$ and serum Free $\mathrm{T}_{4}<0.93 \mathrm{ng} / \mathrm{dl}$ ) [Table 1]. None had subclinical or overt hyperthyroidism.

Among the 13 patients of subclinical hypothyroidism, 11 were female and 2 were male patients. Therefore, the percentages of SCH among female and male patients were $22 \%$ and $4 \%$ respectively.

The mean age in $\mathrm{SCH}$ patients was $58.77 \pm 5.47$ years, whereas the mean age in euthyroid patients was $56.98 \pm 7.49$ years, the difference was not statistically significant ( $P$ value: 0.304$)$.

\section{Clinical profile of subclinical hypothyroid patients}

Among the 13 subclinical hypothyroid patients detected in the study, $3(23 \%)$ patients had clinical features suggestive of hypothyroidism. Goiter was detected in $2(15.4 \%)$ patients of SCH. Table 2 enlists the clinical profile of patients SCH patients who presented with each clinical feature of hypothyroidism.

$\mathrm{SCH}$ patients having symptoms/signs of hypothyroidism were compared with SCH patients without symptoms/signs of hypothyroidism with respect to serum free $\mathrm{T}_{3}$, free $\mathrm{T}_{4}$ and TSH values [Table 3]. Statistically significant difference was noted in all the above three biochemical variables between the two groups.

\section{Blood pressure}

The mean SBP of the $13 \mathrm{SCH}$ patients was $137.38 \pm 11.59 \mathrm{~mm}$ $\mathrm{Hg}$, whereas, the mean DBP was $79.69 \pm 8.40 \mathrm{~mm} \mathrm{Hg}$. Systemic hypertension was present in $6(46 \%)$ of the $13 \mathrm{SCH}$ patients. All the above 6 patients were known cases of hypertension and were on regular antihypertensive drug treatment; and had a mean duration of hypertension of $5.5 \pm 3.94$ years.

\section{Body mass index (BMI)}

BMI, which was calculated for all 100 T2DM patients was used to compare the $13 \mathrm{SCH}$ patients with 84 euthyroid subjects. SCH patients had a mean BMI of $29.70 \pm 3.77 \mathrm{~kg} / \mathrm{m}^{2}$ whereas euthyroid patients had a mean BMI of $27.35 \pm 4.36 \mathrm{~kg} / \mathrm{m}^{2}$, which was not statistically significant ( $P$ value 0.054$)$.

\section{Chronic complications of diabetes mellitus Microvascular complications}

Among $13 \mathrm{SCH}$ patients, 6 (46\%) had one or more microvascular complication of DM i.e., nephropathy/retinopathy/neuropathy. 6

\begin{tabular}{lcccc}
\multicolumn{6}{l}{ Table 1: Gender distribution of thyroid dysfunction } \\
\hline Gender & Total number of patients & Euthyroidism, $\boldsymbol{N}(\%)$ & Subclinical hypothyroidism, $\boldsymbol{N}(\%)$ & Overt hypothyroidism, $\boldsymbol{N}(\%)$ \\
\hline Female & 50 & $37(74)$ & $11(22)$ & $02(4)$ \\
Male & 50 & $47(94)$ & $02(4)$ & $01(2)$ \\
Total & 100 & $84(84)$ & $13(13)$ & $03(3)$ \\
\hline
\end{tabular}


(46\%) SCH patients had diabetic retinopathy, 3 (23\%) SCH patients had diabetic nephropathy, 2 (15\%) SCH patients had diabetic neuropathy.

The $6 \mathrm{SCH}$ patients with diabetic microvascular complication had a mean duration of DM of 8.83 years, mean HbA1c of $7.61 \%$ and mean TSH of $7.21 \mu \mathrm{IU} / \mathrm{ml}$. Three out of the 6 patients had systemic hypertension and were on treatment for the same. SCH patients with diabetic microvascular complication were compared with SCH patients without microvascular complication [Table 4], with respect to the duration of DM, serum HbA1c levels and serum TSH. Statistically significant difference was observed between the two groups in duration of DM ( $P$ value 0.002$)$, serum TSH level ( $P$ value 0.004$)$, but not in serum HbA1c level.

\section{Diabetic retinopathy}

Diabetic retinopathy was detected in $6 \mathrm{SCH}$ patients, i.e. $46 \%$ of $\mathrm{SCH}$ patients in the study. All 6 of these patients had non-proliferative

\begin{tabular}{lc}
\hline $\begin{array}{l}\text { Table 2: Clinical profile of diabetic patients with } \\
\text { subclinical hypothyroidism }\end{array}$ \\
\hline Clinical features & $\begin{array}{c}\text { \% of SCH patients } \\
\text { with the symptom }\end{array}$ \\
\hline Symptom of hypothyroidism & 23 \\
Dry skin & 23 \\
Fatigue & 15.4 \\
Poorer memory & 7.7 \\
Cold intolerance & 7.7 \\
Constipation & \\
Clinical signs of hypothyroidism & 23 \\
Dry coarse skin & 7.7 \\
Cool peripheral extremities & \\
\hline $\mathrm{SCH}=$ Subclinical hypothyroidism &
\end{tabular}

diabetic retinopathy. None of the SCH patients had any evidence of proliferative diabetic retinopathy or macular edema.

$\mathrm{SCH}$ patients with diabetic retinopathy were compared with $\mathrm{SCH}$ patients without retinopathy with respect to the duration of DM, serum HbA1c levels and serum TSH.

SCH patients with diabetic retinopathy had a mean serum TSH value of $7.21 \pm 1.34 \mu \mathrm{IU} / \mathrm{ml}$, mean serum HbA1c of $7.61 \pm 2.15 \%$ and mean duration of DM being $8.83 \pm 2.54$ years. SCH patients without retinopathy had mean serum TSH of $4.90 \pm 0.55 \mu \mathrm{IU} / \mathrm{ml}$, mean serum HbA1c of $8.04 \pm 1.58 \%$ and mean duration of DM being $3.85 \pm 1.80$ years. Statistically significant difference between the two groups was observed in duration of diabetes ( $P$ value 0.002$)$ and serum TSH levels ( $P$ value 0.004$)$.

\section{Diabetic nephropathy}

Diabetic nephropathy was observed in $3 \mathrm{SCH}$ patients, comprising $23 \%$ of all the SCH patients in the study. All the above 3 patients had nephropathy in the form of microalbuminuria. Blood urea and serum creatinine levels were within normal range in all the $\mathrm{SCH}$ patients. Comparison was done between SCH patients with nephropathy and SCH patients without evidence of diabetic nephropathy, based on duration of DM, serum HbA1c levels and serum TSH level.

SCH patients with diabetic nephropathy had a mean serum TSH value of $7.29 \pm 1.77 \mu \mathrm{IU} / \mathrm{ml}$, mean serum HbA1c of $8.73 \pm 2.45 \%$ and mean duration of DM being $8 \pm 2.94$ years. SCH patients without nephropathy had mean serum TSH of $5.57 \pm 1.17 \mu \mathrm{IU} / \mathrm{ml}$, mean serum HbA1c of $7.58 \pm 1.57 \%$ and mean duration of DM being $5.6 \pm 3.2$ years. No statistically significant difference was found between the two groups in any of the above study variables.

\begin{tabular}{|c|c|c|c|c|}
\hline TFT parameters & SCH patients & Number of patients & Mean value \pm SD & $P$ value \\
\hline \multirow[t]{2}{*}{ Free $\mathrm{T}_{3}$} & with clinical features of hypothyroidism & 3 & $2.77 \pm 0.12 \mathrm{ng} / \mathrm{dl}$ & 0.038 \\
\hline & without clinical features of hypothyroidism & 10 & $2.88 \pm 0.55 \mathrm{ng} / \mathrm{dl}$ & \\
\hline \multirow[t]{2}{*}{ Free $\mathrm{T}_{4}$} & with clinical features of hypothyroidism & 3 & $1.01 \pm 0.07 \mathrm{ng} / \mathrm{dl}$ & 0.032 \\
\hline & without clinical features of hypothyroidism & 10 & $1.23 \pm 0.14 \mathrm{ng} / \mathrm{dl}$ & \\
\hline \multirow[t]{2}{*}{ TSH } & with clinical features of hypothyroidism & 3 & $8.15 \pm 0.57 \mu \mathrm{lU} / \mathrm{ml}$ & 0.00004 \\
\hline & without clinical features of hypothyroidism & 10 & $5.31 \pm 1.03 \mu \mathrm{lU} / \mathrm{ml}$ & \\
\hline
\end{tabular}

$\mathrm{SCH}=$ Subclinical hypothyroidism, SD = Standard deviation, TSH = Thyroid-stimulating hormone, TFT = Thyroid function tests

\begin{tabular}{|c|c|c|c|c|}
\hline Study variable & SCH patients & No. of patients & Mean value $\pm S D$ & $P$ value \\
\hline \multirow[t]{2}{*}{ Duration of DM } & with microvascular complication & 6 & $8.83 \pm 2.54$ years & 0.002 \\
\hline & without microvascular complication & 7 & $3.85 \pm 1.80$ years & \\
\hline \multirow[t]{2}{*}{ Serum HbA1C } & with microvascular complication & 6 & $7.61 \pm 2.15 \%$ & 0.929 \\
\hline & without microvascular complication & 7 & $8.04 \pm 1.58 \%$ & \\
\hline \multirow[t]{2}{*}{ Serum TSH } & with microvascular complication & 6 & $7.21 \pm 1.34 \mu \mathrm{lU} / \mathrm{ml}$ & 0.004 \\
\hline & without microvascular complication & 7 & $4.90 \pm 0.55 \mu \mathrm{lU} / \mathrm{ml}$ & \\
\hline
\end{tabular}

$\mathrm{SCH}=$ Subclinical hypothyroidism, SD = Standard deviation, $\mathrm{DM}=$ Diabetes mellitus, $\mathrm{TSH}=$ Thyroid-stimulating hormone, $\mathrm{HbA} 1 \mathrm{C}=\mathrm{Hemog}$ lobin A1C 


\section{Diabetic neuropathy}

Diabetic neuropathy was present in $2(15.4 \%)$ SCH patients. Both of the 2 patients had bilateral lower limb sensory-motor polyneuropathy. Comparison was performed between SCH patients with diabetic neuropathy and $\mathrm{SCH}$ patients without diabetic neuropathy, based on the duration of DM, serum HbA1c levels and serum TSH level.

SCH patients with diabetic neuropathy had a mean serum TSH value of $7.03 \pm 1.60 \mu \mathrm{IU} / \mathrm{ml}$, mean serum HbA1c of $7.87 \pm 2.59 \%$ and mean duration of DM being $9 \pm 3.08$ years. SCH patients without neuropathy had mean serum TSH of $5.49 \pm 1.21 \mu \mathrm{IU} / \mathrm{ml}$, mean serum HbA1c of $7.83 \pm 1.44 \%$ and mean duration of DM being $4.8 \pm 2.51$ years. Statistically significant difference between the two groups was observed in duration of DM $(P=0.038)$.

\section{Macrovascular complications of DM}

Among $13 \mathrm{SCH}$ patients, coronary artery disease was evident in $1(7.7 \%) \mathrm{SCH}$ patient with a positive history of ischemic heart disease and was confirmed by 2D echocardiography. There was no clinical evidence of peripheral arterial disease or cerebrovascular disease in any of the thirteen SCH patients in the study.

\section{Metabolic profile of SCH patients Glycemic profile}

The glycemic profile including FBS, PPBS and serum HbA1c, of $\mathrm{SCH}$ patients of T2DM was compared with that of euthyroid counterparts in the study. Among the $13 \mathrm{SCH}$ patients, the mean FBS value was $148.23 \pm 37.77 \mathrm{mg} \%$, mean PPBS value was $240.30 \pm 65.06 \mathrm{mg}^{\circ}$, mean serum HbA1c was $7.84 \pm 1.87 \%$. Among the 84 euthyroid patients, the mean FBS value was $157.04 \pm 60.27 \mathrm{mg} \%$, mean PPBS was $242.09 \pm 79.50 \mathrm{mg} \%$ and mean serum HbA1c was $8.09 \pm 2.15 \%$. Statistically significant difference was not observed in any of the above study variables between the two groups; although, $\mathrm{SCH}$ patients had relatively low mean values of FBS, PPBS and serum HbA1c, compared with euthyroid subjects.

\section{Antidiabetic medications}

Among the $13 \mathrm{SCH}$ patients, 2 (15.4\%) patients were on insulin therapy along with oral hypoglycemic agents, 4 (30.8\%) patients were on more than 2 classes of oral hypoglycemic drugs, the remaining 7 (53.8\%) SCH patients were on not more than 2 classes of oral hypoglycemic drugs.

\section{Fasting lipid profile}

Among the $13 \mathrm{SCH}$ patients, 6 (46\%) patients had dyslipidemia. All the 6 patients were known cases of dyslipidemia and were on medication for the same. The fasting lipid profile of SCH patients of T2DM was compared with that of euthyroid counterparts. Among the $13 \mathrm{SCH}$ patients, the mean serum total cholesterol was $175.69 \pm$ $28.05 \mathrm{mg} \%$, mean serum low-density lipoprotein (LDL) was 102.30 $\pm 27.3 \mathrm{mg} \%$, mean serum high-density lipoprotein (HDL) was 38.14 $\pm 4.12 \mathrm{mg} \%$, mean serum triglycerides (TG) was $178 \pm 66.03 \mathrm{mg} \%$. Among the 84 euthyroid subjects, the mean serum total cholesterol was $164.35 \pm 32.73 \mathrm{mg}^{\%}$, mean serum LDL was $94.64 \pm 28.87$ $\mathrm{mg}^{0} \%$, mean serum HDL was $40.06 \pm 6.94 \mathrm{mg} \%$, mean serum TG was $151.10 \pm 77.03 \mathrm{mg} \%$. Although SCH patients had higher mean values of serum total cholesterol, LDL, TG and lower mean value of serum HDL, compared with euthyroid subjects, the difference was not statistically significant.

\section{Serum levels of anti-TPO antibodies}

Among the $13 \mathrm{SCH}$ patients, serum level of anti-TPO antibodies was elevated in 11 patients ( $84.6 \%$ of SCH patients). $10 \mathrm{SCH}$ patients with elevated anti-TPO antibody were female, one was male. The remaining 2 SCH patients had serum levels of anti-TPO antibodies within normal limits. Therefore, serum anti-TPO antibody levels were elevated in $91 \%$ of female SCH patients and in 50\% of male SCH patients.

\section{DISCUSSION}

$\mathrm{SCH}$ is defined as a serum thyroid-stimulating hormone (TSH) level above the upper limit of normal despite normal levels of serum free thyroxine. ${ }^{[6]} \mathrm{SCH}$ or mild thyroid failure is a common problem, with a prevalence of $3-8 \%$ in the population without known thyroid disease. ${ }^{[7,8]}$ The prevalence increases with age and is higher in women. After the sixth decade of life, the prevalence in men approaches that of women, with a combined prevalence of $10 \%$. Antithyroid antibodies can be detected in $80 \%$ of patients with $\mathrm{SCH}$ and $80 \%$ of patients with $\mathrm{SCH}$ have a serum TSH of less than $10 \mathrm{mIU} / \mathrm{L}$.

Although studies have pointed to some adverse effects of SCH, no consensus exists as to the clinical importance of the adverse effects and the benefits of levothyroxine therapy, particularly for the $80 \%$ of patients with SCH who have a TSH of less than $10 \mathrm{mIU} / \mathrm{L}$, because of the different levels of TSH and degrees of thyroid dysfunction in these studies. ${ }^{[9,10]}$

Patients with SCH have a high rate of progression to clinically overt hypothyroidism, 2.6\% each year if TPO antibodies are absent and $4.3 \%$ if they are present. ${ }^{[11]}$

The Colorado Health Fair study showed that the mean total cholesterol level was $216 \mathrm{mg} / \mathrm{dL}$ for euthyroid patients and $224 \mathrm{mg} / \mathrm{dL}$ for patients with SCH. ${ }^{[12]}$ Several randomized studies have shown reduction of LDL cholesterol by levothyroxine therapy. However, most of the studies showing benefit are not categorized for serum TSH levels of 5.0-10.0 mIU/L. A meta-analysis of 13 studies concluded that the lipid profile improved with therapy. ${ }^{[13]}$ In a 2004 review, data were considered insufficient to show benefits of levothyroxine therapy on lipid levels. ${ }^{[14]}$

Several recent meta- analysis of observational studies found an association between SCH and coronary artery disease. ${ }^{[15-17]}$ Diabetic patients have a higher prevalence of thyroid disorders compared with the normal population. Because patients with one organ-specific autoimmune disease are at risk of developing other autoimmune disorders and thyroid disorders are more common in females, up to $30 \%$ of female type 1 diabetic patient have thyroid disease. The 
rate of postpartum thyroiditis in diabetic patients is three times that in normal women. A number of reports have also indicated a higher than normal prevalence of thyroid disorders in type 2 diabetic patients, with hypothyroidism being the most common disorder. ${ }^{[1]}$

Prevalence of thyroid disease in the general population is $6.6 \% .^{[1]}$ Perros et al. ${ }^{[18]}$ found that the prevalence of thyroid disease in diabetics is $13.4 \%$ and was highest in type 1 diabetic females and lowest in type 2 diabetic males. Celani et al..$^{[3]}$ found that prevalence of thyroid disease in type 2 diabetics was $31.4 \%$, out of which $\mathrm{SCH}$ was most common form $(48.3 \%)$, followed by subclinical hyperthyroidism (24.2\%), overt hypothyroidism (23.1\%) and overt hyperthyroidism (4.4\%). The study even reported that $33 \%$ of type 2 diabetics with thyroid disease had high levels of anti-TPO antibodies. Fernández-Real $e t$ al. ${ }^{[2]}$ reported that thyroid function tests are intrinsically linked to variables of insulin resistance and endothelial function, therefore implying the possibility that underlying factors lead simultaneously to increased serum TSH, insulin resistance, ensuing dyslipidemia and altered endothelial function.

In hypothyroidism, glucose homeostasis is also affected although its clinical impact is less obvious. Decreased glucose disposal (as compared with euthyroid subjects) has been proved in hypothyroid patients. Hypothyroidism results in unimpaired or decreased liver glucose output thereby compensating for insulin resistance present in peripheral tissues and accounting for the diminished insulin requirement for glycemic control in hypothyroid diabetic patients. Insulin resistance has been also reported in subclinical hypothyroidism, adding one more possible mechanism to the association of sub-clinical hypothyroidism and cardiovascular risk.

Only a few studies have explored the effects of sub-clinical thyroid dysfunction in the diabetic population. Patients with SCH had a higher prevalence of retinopathy, especially the sight-threatening form, when compared with their type 2 diabetic euthyroid counterparts. ${ }^{[19]}$ Both $\mathrm{SCH}$ and hyperthyroidism have been linked to increased cardiovascular risk.

In the present study, serum TPO antibody elevation was seen in 11 (84.6\%) SCH patients, indicating thyroid disease of autoimmune etiology. In a study by Celani et al. ${ }^{[3]}$ it was observed that $61.3 \% \mathrm{SCH}$ patients with T2DM had elevated serum anti-TPO antibody levels. Celani et al. ${ }^{[3]}$ also observed that the remaining $38.7 \% \mathrm{SCH}$ patients who were negative for anti-TPO antibody, showed decreased serum TSH concentrations when retested after 2 months of adequate treatment for DM.

\section{CONCLUSION}

SCH is common among type 2 diabetic patients, especially in females. It is most commonly secondary to autoimmune thyroid disease. Microvascular complications are commonly observed in this group of patients with dual endocrinal disorder treating physicians should routinely screen $\mathrm{SCH}$ in patients with diabetes mellitus to prevent complications.

\section{REFERENCES}

1. Wu P. Tyroid disease and diabetes. Clin Diabetes 2000;18:38-41.

2. Fernández-Real JM, López-Bermejo A, Castro A, Casamitjana R, Ricart W. Thyroid function is intrinsically linked to insulin sensitivity and endothelium-dependent vasodilation in healthy euthyroid subjects. J Clin Endocrinol Metab 2006;91:3337-43.

3. Celani MF, Bonati ME, Stucci N. Prevalence of abnormal thyrotropin concentrations measured by a sensitive assay in patients with type 2 diabetes mellitus. Diabetes Res 1994;27:15-25.

4. Fatourechi V. Subclinical hypothyroidism: An update for primary care physicians. Mayo Clin Proc 2009;84:65-71.

5. Shrier DK, Burman KD. Subclinical hyperthyroidism: Controversies in management. Am Fam Physician 2002;65:431-8.

6. Cooper DS. Clinical practice. Subclinical hypothyroidism. N Engl J Med 2001;345:260-5.

7. Hollowell JG, Staehling NW, Flanders WD, Hannon WH, Gunter EW, Spencer CA, et al. Serum TSH, T(4), and thyroid antibodies in the United States population (1988 to 1994): National health and nutrition examination survey (NHANES III). J Clin Endocrinol Metab 2002;87:489-99.

8. Karmisholt J, Andersen S, Laurberg P. Variation in thyroid function tests in patients with stable untreated subclinical hypothyroidism. Thyroid 2008;18:303-8.

9. Chu JW, Crapo LM. The treatment of subclinical hypothyroidism is seldom necessary. J Clin Endocrinol Metab 2001;86:4591-9.

10. McDermott MT, Ridgway EC. Subclinical hypothyroidism is mild thyroid failure and should be treated. J Clin Endocrinol Metab 2001;86:4585-90.

11. Vanderpump MP, Tunbridge WM, French JM, Appleton D, Bates D, Clark $\mathrm{F}$, et al. The incidence of thyroid disorders in the community: A twenty-year follow-up of the Whickham survey. Clin Endocrinol (Oxf) 1995;43:55-68.

12. Canaris GJ, Manowitz NR, Mayor G, Ridgway EC. The Colorado thyroid disease prevalence study. Arch Intern Med 2000;160:526-34.

13. Danese MD, Ladenson PW, Meinert CL, Powe NR. Clinical review 115: Effect of thyroxine therapy on serum lipoproteins in patients with mild thyroid failure: A quantitative review of the literature. J Clin Endocrinol Metab 2000;85:2993-3001.

14. Surks MI, Ortiz E, Daniels GH, Sawin CT, Col NF, Cobin RH, et al. Subclinical thyroid disease: Scientific review and guidelines for diagnosis and management. JAMA 2004;291:228-38.

15. Rodondi N, Aujesky D, Vittinghoff E, Cornuz J, Bauer DC. Subclinical hypothyroidism and the risk of coronary heart disease: A meta-analysis. Am J Med 2006;119:541-51.

16. Ochs N, Auer R, Bauer DC, Nanchen D, Gussekloo J, Cornuz J, et al. Meta-analysis: Subclinical thyroid dysfunction and the risk for coronary heart disease and mortality. Ann Intern Med 2008;148:832-45.

17. Singh S, Duggal J, Molnar J, Maldonado F, Barsano CP, Arora R. Impact of subclinical thyroid disorders on coronary heart disease, cardiovascular and all-cause mortality: A meta-analysis. Int J Cardiol 2008;125:41-8.

18. Perros P, McCrimmon RJ, Shaw G, Frier BM. Frequency of thyroid dysfunction in diabetic patients: Value of annual screening. Diabet Med 1995;12:622-7.

19. Yang JK, Liu W, Shi J, Li YB. An association between subclinical hypothyroidism and sight-threatening diabetic retinopathy in type 2 diabetic patients. Diabetes Care 2010;33:1018-20.

How to cite this article: Manjunath SC, Krishnamurthy V, Puttaswamy BK, Prabhu S, Vishwanathaiah PM. Prevalence of subclinical thyroid disorders in type 2 diabetes mellitus. Int $\mathrm{J}$ Med Public Health 2013;3:330-4.

Source of Support: Nil, Conflict of Interest: None declared. 